\title{
The Natural History of IgE-Mediated Food Allergy: Can Skin Prick Tests and Serum-Specific IgE Predict the Resolution of Food Allergy?
}

\author{
Rachel L. Peters ${ }^{1,2}$, Lyle C. Gurrin ${ }^{1,3}$, Shyamali C. Dharmage ${ }^{1,3}$, Jennifer J. Koplin ${ }^{1,3}$ \\ and Katrina J. Allen ${ }^{1,2,4, *}$
}

1 Murdoch Childrens Research Institute, Parkville, VIC 3052, Australia;

E-Mails: rachel.peters@mcri.edu.au (R.L.P.); 1gurrin@unimelb.edu.au (L.C.G.);

s.dharmage@unimelb.edu.au (S.C.D.); Jennifer.koplin@mcri.edu.au (J.J.K.)

2 Department of Paediatrics, University of Melbourne, Parkville, VIC 3052, Australia

3 Centre for Molecular, Environmental, Genetic and Analytic Epidemiology, University of Melbourne, Parkville, VIC 3010, Australia

4 Department of Allergy and Immunology, Royal Children's Hospital, Parkville, VIC 3052, Australia

* Author to whom correspondence should be addressed; E-Mail: katie.allen@rch.org.au; Tel.: +613-9345-4870; Fax: +613-9345-4848.

Received: 2 August 2013; in revised form: 16 September 2013 / Accepted: 8 October 2013 / Published: 15 October 2013

\begin{abstract}
IgE-mediated food allergy is a transient condition for some children, however there are few indices to predict when and in whom food allergy will resolve. Skin prick test (SPT) and serum-specific IgE levels (sIgE) are usually monitored in the management of food allergy and are used to predict the development of tolerance or persistence of food allergy. The aim of this article is to review the published literature that investigated the predictive value of SPT and SIgE in development of tolerance in children with a previous diagnosis of peanut, egg and milk allergy. A systematic search identified twenty-six studies, of which most reported SPT or SIgE thresholds which predicted persistent or resolved allergy. However, results were inconsistent between studies. Previous research was hampered by several limitations including the absence of gold standard test to diagnose food allergy or tolerance, biased samples in retrospective audits and lack of systematic protocols for triggering re-challenges. There is a need for population-based, prospective studies that use the gold standard oral food challenge (OFC) to diagnose food allergy at
\end{abstract}


baseline and follow-up to develop SPT and SIgE thresholds that predict the course of food allergy.

Keywords: food allergy; natural history; tolerance; skin prick test; serum-specific immunoglobulin E; hen's egg; peanut; cow's milk

\section{Introduction}

IgE-mediated food allergy is an increasing public health concern in the pediatric population. It commonly presents in infancy and together with eczema, are often the first manifestations of the atopic march, predisposing children to develop asthma and other allergic diseases later in life [1-4]. Although infants can, in theory, be allergic to any food, the majority of reactions are to one of nine foods: peanut, hen's egg, cow's milk, wheat, soya, tree nuts, sesame, shellfish and kiwi fruit [5]. Reports on the prevalence of food allergy vary by region and food, as well as study design and the measure of food allergy [6,7]. A recent systematic review reported that at least $1 \%-2 \%$ and up to $10 \%$ of the US population suffers from food allergies, although this estimate includes self-report, skin prick test (SPT), serum-specific IgE (sIgE) and oral food challenges (OFC) as measures of food allergy [7]. More recently, an Australian study found that $10 \%$ of 12 -month old infants were challenge-confirmed allergic to one or more foods [8].

Food allergy is a transient condition for some children, although reports on the rate of resolution vary between studies. Around $20 \%$ of peanut allergy resolves in childhood [9-12], although some reports suggest that up to 50\% of peanut allergy is transient [13-15]. Egg and milk allergy generally have a better prognosis with the majority of children expected to outgrow their allergy by school age [16-21]. Recent reports, however, suggest that for both egg and milk allergy, resolution is not occurring as quickly as previously thought, with allergy persisting well into adolescence and beyond [22,23]. It is not clear if the natural history of food allergy is changing or if it is simply a reflection of different study designs and populations. The latter studies were recruited from tertiary referral centers and may be overrepresented by children with more severe food allergy, skewing the rate of resolution.

At this stage, there are few indices to predict when and in whom tolerance will develop. This presents the problem of determining the optimal time to subject the child to further OFC while considering their existing risk of reaction. Delaying OFC could subject the child to further unnecessary dietary restrictions and reduced quality of life. Conversely frequent OFC is resource intensive and potentially exposing the child to unnecessary adverse reactions. Currently the only tool available for monitoring the natural history is IgE levels, either by SPT or sIgE. It is common practice for clinicians to monitor IgE levels every 1-2 years and if they drop below a certain threshold (i.e., the 95\% PPV for diagnosis of food allergy) then a food challenge will be ordered to confirm or refute the presence of food allergy. Alternatively if SPT or sIgE to that particular food is negative, or there is a history of accidental exposure without reaction which supports liberation of the diet, then home introduction may be offered without the need for formal OFC. It should be noted that despite low SPT, that some children may not be suitable candidates for home introduction, as in the case of unstable asthma or past 
history of anaphylaxis. Finally, monitoring SPT and sIgE may help identify children who are unlikely to develop tolerance, and could therefore be considered for interventions such as oral immunotherapy (OIT).

SPT and sIgE thresholds with 95\% positive predictive value (PPV) for food allergy are frequently utilized in clinical practice to reduce the need for OFC. Children with SPT or sIgE level above these thresholds have a high probability of OFC-confirmed food allergy at diagnosis [24-30]. In a similar fashion, SPT and SIgE are used for following the natural history of the condition to assess whether tolerance may have developed. If carefully and systematically measured 95\% PPV thresholds were developed, they could be used to determine the optimal time to review children and the necessity of repeat OFC in food allergic children.

We have previously published a systematic review on SPT with 95\% PPV to diagnose food allergy in children [31]. The aim of this paper is to review the current literature on the relationship between SPT and SIgE and 95\% PPV of these measures for tolerance development of childhood IgE-mediated food allergy, i.e., in a child previously diagnosed with food allergy, what are the 95\% PPV for persistent food allergy or the development of tolerance? This review focuses on peanut, egg and milk allergy as they are responsible for the majority of allergic reactions in childhood.

\section{Publications that Reported on SPT, sIgE and the Development of Tolerance in Food} Allergic Children

A search of PubMed, Medline and Embase was conducted using the search terms "food allergy" or "food hypersensitivity" and "immune tolerance" or "prognosis" or "natural history" and "immunoglobulin E" or "skin test" and "peanut" or "egg" or "milk". Studies were included if they met the following criteria: (1) contained a sample of children diagnosed with IgE-mediated food allergy; (2) tested for persistent or resolved food allergy by OFC and (3) investigated the relationship between either the change in SPT and SIgE over the course of follow-up, or SPT and sIgE measured at follow-up, and whether it could predict persistent or resolved food allergy. Studies that included both children with IgE- and non-IgE mediated food allergy, yet didn't differentiate between these two types of food allergy in the results, were excluded from the review. Studies that reported SPT wheal size as grades, rather than absolute numbers, were also excluded.

The search of the electronic databases produced 386 results. Three-hundred and twenty-seven were immediately excluded because they were oral immunotherapy trials or review articles, did not examine egg, peanut or milk allergy, or did not describe the association between SPT or sIgE and the prognosis of food allergy. The remaining 59 articles were retrieved. A further 40 articles were excluded from the review because they did not meet the inclusion criteria. Reference lists of included articles and review articles were manually searched for potentially relevant papers which yielded another seven articles that met the inclusion criteria. A total of 26 articles are included in this review. They were published between 1982 and 2013. 


\section{How Comparable are the Studies: Limitations of and Variations across the Studies}

On reviewing the literature, several limitations of previous studies have become evident which hinders comparisons between studies. These limitations include the absence of the gold standard test to diagnose food allergy or tolerance, biased samples in retrospective audits and lack of systematic protocols for triggering re-challenges. Study designs were also heterogeneous with regards to subject selection, age of participants and period of follow-up, making comparisons between studies difficult.

Previous research suggests that if food allergy is to resolve then it is more likely to do so at a younger age $[17,32,33]$. If a study followed older children, they were less likely to observe the development of tolerance, compared to a study that had followed a cohort since infancy. The diagnostic cut offs of $95 \%$ PPV of SPT wheal size and sIgE are age-dependent, that is, thresholds differ when stratified by age (infants versus children and adolescents) [29,34,35]. Therefore it is likely that the prognostic cut offs of $95 \%$ PPV of SPT and SIgE may also vary with age. Both these factors suggest that studies examining the natural history of food allergy should be restricted to children of a similar age to ensure homogeneity in the development of PPVs, which was not usually the case with the studies considered in this review.

As with all food allergy research, the method to diagnose food allergy underpins the reliability of the results. The diagnosis of food allergy at baseline varied with only few studies having confirmed food allergy at baseline with the gold standard OFC. Many studies were retrospective and recruited children with a previous diagnosis of food allergy, based on clinical history and having a positive SPT or SIgE to the food, with or without OFC. Some studies included participants who had positive SPT or SIgE but no known history of exposure to the allergen, or participants who had SPT or sIgE greater than a particular threshold $[10,22,36]$. With each of these scenarios, there is a possibility that some children were only sensitised, but never actually allergic at baseline, which creates selection bias by including non-allergic participants.

In addition, retrospective audits may be subject to selection bias and inclusion criteria are often poorly defined. Children with complex allergic disease (e.g., multiple food allergies or coexisting atopic disease) are likely to be over-represented among studies that recruited participants from tertiary care settings compared to studies where participants were drawn from the general community. Resolution of milk allergy is reported to be higher in population-based studies, compared to those recruited from tertiary allergy clinics as they include the full spectrum of cases $[17,33,37,38]$. High loss to follow up may also bias the results, particularly in retrospective studies recruited from tertiary clinics, where children who have developed tolerance may be less likely to return for follow up assessment, and therefore the true rate of tolerance may be underestimated.

Although most studies confirmed the resolution of food allergy with OFC, there was a lack of systematic protocols recording reasons for triggering OFC or time intervals for repeat OFC for tolerance detection. Several studies stated that children were offered repeat OFC when clinically indicated, but did not always define what that meant $[14,39,40]$. In the case of retrospective studies, post hoc definition of reasons for challenge is likely to be problematic. Based on the current standard of practice, potential triggers for challenge could include SPT or SIgE approaching a negative result or if the child had an accidental exposure with no reaction. Other scenarios encountered in this review were to only offer OFC when SPT or sIgE fell below a predetermined threshold or assuming children 
with SPT or sIgE above a particular threshold were still allergic. Using a predetermined SPT or sIgE threshold as a marker for allergy or tolerance, in a study examining the usefulness of the test to predict that outcome, may bias the results as it acts as a self-fulfilling prophecy, e.g., the test will have high predictability to persistent allergy when all participants above that level are assumed to remain allergic. In addition, only offering OFC if SPT or SIgE is negative is likely to miss some cases of tolerance that have developed despite the test result remaining elevated.

\section{What do These Studies Tell Us?}

Twenty-six studies were identified that examined the use of SPT or sIgE at or during the course of follow-up and all except four studies reported that there was an association between these tests and the prognosis of food allergy $[12,39,41,42]$. At follow-up, SPT and sIgE was larger in children whose food allergy persisted [20,43-46] and SPT and SIgE decreased over time in children with resolved allergy $[10,15,22,47,48]$. sIgE was also observed to decrease in children with persistent food allergy, but this decrease was not as sharp as that observed in children with resolved food allergy $[22,33]$.

\subsection{Peanut Allergy}

Eight studies examined the association between SPT and/or sIgE and the prognosis of peanut allergy. Six studies showed SPT or SIgE thresholds that predicted persistent or resolved peanut allergy whilst two studies found no association between SPT or sIgE and development of tolerance to peanut $[12,39]$. Characteristics and results of these studies are presented in Table 1.

Most studies were retrospective, that is, either retrospective chart reviews or recruited participants retrospectively with prospective follow-up. Only two studies used OFC to confirm the diagnosis of peanut allergy in all participants at baseline, but unfortunately these studies were both limited by very small sample sizes and neither were able to demonstrate an association between SPT or sIgE and resolution of peanut allergy [12,39]. Several studies used a predetermined SPT/sIgE threshold to either diagnose peanut allergy at baseline or persistent allergy at follow-up or simply excluded participants with sIgE above a particular threshold, which makes comparisons between these studies difficult $[9,10,15]$. At follow-up, only one study offered OFC to all participants irrespective of SPT wheal size, however parents were given the option to opt-out if SPT $\geq 8 \mathrm{~mm}$ [15]. The remaining studies only offered OFC if SPT or sIgE fell below a pre-determined threshold, which varied between studies $[9,10,13-15,40]$.

In the study by Ho et al., 267 children under 2 years of age were recruited with a diagnosis of peanut allergy based on SPT $\geq 4 \mathrm{~mm}$. Children were reviewed every 1-2 years, for up to 8 years, and offered OFC when SPT fell below the previously reported 95\% PPV for their age. The authors reported that $\mathrm{SPT} \geq 6 \mathrm{~mm}, \mathrm{sIgE} \geq 3 \mathrm{kU} / \mathrm{L}$ before 2 years of age or an increase in peanut SPT of $3 \mathrm{~mm}$ or more between 1 and 4 years of age was predictive of persistent peanut allergy. Decreasing SPT was a good indicator of tolerance development but as the authors themselves discuss, those with a persistently elevated SPT were not routinely offered OFC, so the results were biased to persistence of allergic disease in those with persistently elevated SPT and overestimated the PPV [10]. 
Table 1. Studies reporting on SPT and SIgE and the prognosis of PEANUT allergy.

\begin{tabular}{|c|c|c|c|c|c|c|c|c|c|}
\hline Author & $\mathbf{N}$ & Study design & Diagnosis of food allergy & Age $^{1}$ & $\begin{array}{l}\text { Follow-up } \\
\text { period }\end{array}$ & $\begin{array}{c}\text { Follow-up } \\
\text { diagnosis }\end{array}$ & Resolution & SPT (mm) & $\operatorname{sIgE}\left(k U_{A} / L\right)$ \\
\hline $\begin{array}{c}\text { Mudd et al. } \\
2009 \text { [39] }\end{array}$ & 28 & $\begin{array}{l}\text { Retrospective } \\
\text { chart review }\end{array}$ & OFC & 5 years & $\begin{array}{c}2.8 \text { years } \\
\text { (range } 0.7-10 \\
\text { years) }\end{array}$ & $\begin{array}{l}\text { OFC if clinically } \\
\text { indicated (time, } \\
\text { exposure and } \\
\text { symptom history } \\
\text { since last OFC } \\
\text { or sIgE) }\end{array}$ & $46 \%$ & & $\begin{array}{l}\text { Not predictive } \\
\text { of tolerance }\end{array}$ \\
\hline $\begin{array}{l}\text { Ho et al. } \\
2008[10]\end{array}$ & 267 & Longitudinal & $\mathrm{SPT} \geq 4 \mathrm{~mm}$ & $<2$ years & $\begin{array}{c}\text { Reviewed } \\
\text { every } \\
1-2 \text { years for } \\
\text { up to } 8 \text { years. }\end{array}$ & $\begin{array}{c}\text { OFC offered } \\
\text { when } \\
\text { SPT }<4 \mathrm{~mm} \\
(<2 \text { years old }) \text { or } \\
8 \mathrm{~mm}(>2 \text { years } \\
\text { old })\end{array}$ & $18 \%$ & $\begin{array}{c}\text { Increase SPT } \geq 3 \\
\text { between } 1 \text { and } \\
4 \text { years of age is } \\
\text { predictor of } \\
\text { persistence } \\
\text { SPT } \geq 6 \text { before } \\
2 \text { years predictive } \\
\text { of persistent } \\
\text { allergy }\end{array}$ & $\begin{array}{c}\operatorname{sIgE} \geq 3 \text { before } \\
2 \text { years } \\
\text { predictive of } \\
\text { persistent allergy }\end{array}$ \\
\hline $\begin{array}{c}\text { Nolan et al. } \\
2007 \text { [15] }\end{array}$ & 54 & Prospective & $\begin{array}{l}\text { Clinical history or positive } \\
\mathrm{SPT} / \mathrm{sIgE} \text { with no history } \\
\text { of ingestion. Excluded if } \\
\mathrm{sIgE}>10 \mathrm{kU} \mathrm{A}_{\mathrm{A}} / \mathrm{L} \text {, reaction } \\
\text { in previous } 2 \text { years or } \\
\text { previous severe reaction }\end{array}$ & $\begin{array}{l}6.3 \text { years } \\
\text { (range } \\
3.7-14.8 \\
\text { years) }\end{array}$ & NR & $\begin{array}{l}\text { OFC (irrespective } \\
\text { of SPT however } \\
\text { parents could } \\
\text { opt-out if } \\
\text { SPT } \geq 8 \mathrm{~mm}\end{array}$ & $53 \%$ & $\begin{array}{c}\mathrm{SPT} \geq 7 \mathrm{~mm}, \\
93 \% \mathrm{PPV}\end{array}$ & \\
\hline $\begin{array}{c}\text { Perry et al. } \\
2004[14]\end{array}$ & 173 & $\begin{array}{l}\text { Retrospective } \\
\text { chart review }\end{array}$ & $\begin{array}{c}\text { Clinical history or } \\
\text { SPT/sIgE with no history } \\
\text { of ingestion }\end{array}$ & $\begin{array}{l}4.8 \text { years } \\
\text { (range } \\
1-43 \\
\text { years) }\end{array}$ & NR & $\begin{array}{l}\text { OFC (if clinically } \\
\text { indicated or when } \\
\text { sIgE } 25 \% \\
\text { of previously } \\
\text { reported } \\
95 \% \text { PPV) }\end{array}$ & $59 \%$ & & $\begin{array}{c}<2, \\
50 \% \text { probability } \\
\text { of tolerance }\end{array}$ \\
\hline
\end{tabular}


Table 1. Cont.

\begin{tabular}{|c|c|c|c|c|c|c|c|c|c|}
\hline Author & $\mathbf{N}$ & Study design & Diagnosis of food allergy & Age $^{1}$ & $\begin{array}{c}\text { Follow-up } \\
\text { period }\end{array}$ & $\begin{array}{c}\text { Follow-up } \\
\text { diagnosis }\end{array}$ & Resolution & SPT (mm) & $\operatorname{sIgE}\left(k U_{A} / L\right)$ \\
\hline $\begin{array}{l}\text { Fleischer } \\
\quad \text { et al. } \\
2003[13]\end{array}$ & 84 & $\begin{array}{l}\text { Retrospective } \\
\text { chart review }\end{array}$ & $\begin{array}{c}\text { Clinical history and } \\
\text { SPT/sIgE or OFC; or no } \\
\text { ingestion but positive } \\
\text { SPT/sIgE }\end{array}$ & $>4$ years & NR & $\begin{array}{c}\text { OFC or DBPCFC } \\
\text { if } \operatorname{sIgE}<5\end{array}$ & $55 \%$ & & $\begin{array}{l}\text { sIgE }<2 \text { more } \\
\text { likely to develop } \\
\text { tolerance than } \\
\text { sIgE } 2-5 \mathrm{kU} / \mathrm{L}\end{array}$ \\
\hline $\begin{array}{l}\text { Skolnick } \\
\text { et al. } \\
2001 \text { [9] }\end{array}$ & 223 & $\begin{array}{l}\text { Retrospective } \\
\text { follow-up }\end{array}$ & $\begin{array}{c}\text { Clinical history and } \\
\text { positive SPT, sIgE or OFC; } \\
\text { or positive SPT and SIgE } \\
\text { but no ingestion }\end{array}$ & $\begin{array}{l}1.5 \text { years } \\
(2 \text { months } \\
-15 \text { years })\end{array}$ & NR & $\begin{array}{l}\text { OFC. } \operatorname{sIgE}>20 \\
\text { assumed allergic } \\
\text { sIgE }>10 \text { and } \\
\text { severe reaction, } \\
\text { no OFC (138 not } \\
\text { challenged) }\end{array}$ & $21.5 \%$ & & $\begin{array}{c}\operatorname{sIgE} \geq 5 \\
64 \% \mathrm{PPV} \text { and } \\
61 \% \mathrm{NPV}\end{array}$ \\
\hline $\begin{array}{l}\text { Hourihane } \\
\quad \text { et al. } \\
1998[40]\end{array}$ & 30 & Case-control & Clinical history & $\begin{array}{c}5 \text { years } \\
\text { (range } \\
2-10 \\
\text { years) }\end{array}$ & NR & $\begin{array}{l}\text { OFC if clinically } \\
\text { indicated (recent } \\
\text { non-eventful } \\
\text { exposure or } \\
\text { negative SPT) }\end{array}$ & $50 \%$ & $\begin{array}{c}\text { SPT } \geq 6 \\
100 \% \mathrm{PPV} \text { and } \\
80 \% \mathrm{NPV}\end{array}$ & $\begin{array}{l}\text { Not predictive } \\
\text { of tolerance }\end{array}$ \\
\hline $\begin{array}{l}\text { Sampson } \\
1989[12]\end{array}$ & 10 & Retrospective & DBPCFC & $\begin{array}{l}7.9 \text { years } \\
\text { (range } \\
3-18 \\
\text { years) } \\
\end{array}$ & $1-3$ years & $\begin{array}{l}\text { DBPCFC or } \\
\text { accidental } \\
\text { ingestion }\end{array}$ & $20 \%$ & $\begin{array}{l}\text { Not predictive } \\
\text { of tolerance }\end{array}$ & \\
\hline
\end{tabular}

${ }^{1}$ Age at diagnosis or entry into study; reported as mean or median (range); NR: not reported. 
Nolan et al. completed a prospective study of children referred to a tertiary allergy clinic with a history of peanut allergy or positive sensitisation test with no history of ingestion. Children were excluded if they had a severe reaction within the preceding 2 years or if $\operatorname{sIgE}>10 \mathrm{kU} / \mathrm{L}$. All children were offered OFC, however parents of children with SPT $\geq 8 \mathrm{~mm}$ were given the option to opt-out of the study considering the child's high risk of reaction $(n=2)$. Therefore, the more severe cases of peanut allergy were not represented in this study, limiting the generalisability of results to these cases. In this study, 27 of 51 children were considered to have developed tolerance to peanut on OFC, however 16 of the tolerant children were only sensitised at entry into the study with no known exposure to peanut. It is possible that these children were never allergic to peanut. SPT $\geq 7 \mathrm{~mm}$ had 93\% PPV to persistent peanut allergy although this is limited to children with $\operatorname{sigE}<10 \mathrm{kU}_{\mathrm{A}} / \mathrm{L}$ [15]. A similar result was reported from a case-control study of 30 children with persistent $(n=15)$ and resolved $(\mathrm{n}=15)$ peanut allergy; SPT $\geq 6 \mathrm{~mm}$ had $100 \%$ PPV to persistent peanut allergy and $80 \%$ NPV to resolved peanut allergy [40].

A further three studies have reported $\operatorname{sIgE}$ thresholds that predict persistent or resolved peanut allergy, however the results are likely to be biased towards persistent allergy and overestimated the PPV, because OFC were only offered if sIgE was low. Skolnick et al. reported $\operatorname{sIgE} \geq 5 \mathrm{kU} \mathrm{A}_{\mathrm{A}} / \mathrm{L}$ to have $64 \% \mathrm{PPV}$ to persistent allergy in a retrospective follow-up of 233 children. However, over half of this sample $(n=138)$ were not eligible for OFC at follow-up on the basis of high sIgE [9]. In a retrospective chart review of 173 children diagnosed with peanut allergy by clinical history or positive SPT/sIgE with no history of ingestion, Perry et al. reported that children with $\operatorname{sIgE}<2 \mathrm{kU}_{\mathrm{A}} / \mathrm{L}$ at follow-up should be considered for OFC because it was associated with a $50 \%$ probability of tolerance. However, participants were mostly offered OFC if sIgE was negative or fell to $25 \%$ of previously reported 95\% PPVs. It is possible that they have underestimated the resolution of peanut allergy and in turn, the PPV, by limiting their challenge criteria to children with negative or low SIgE [14]. Fleischer et al. also reported, in a retrospective chart review of 84 children, that those with $\operatorname{sigE}<2 \mathrm{kU} / \mathrm{L}$ were more likely to develop tolerance, however again OFC was only conducted if sIgE was below a given threshold $\left(<5 \mathrm{kU}_{\mathrm{A}} / \mathrm{L}\right)$ [13].

These results suggest that SPT and SIgE may be useful in predicting the persistence of peanut allergy, however most existing studies are biased towards persistent allergy which is likely to overestimate the PPV, because children with high SPT or sIgE were assumed to have persistent allergy or were excluded. More research is needed to qualify if these tests are useful in identifying which children are likely to outgrow their peanut allergy. Furthermore, all studies recruited participants from tertiary allergy clinics, which are likely to be overrepresented by children from the more severe end of the spectrum of food allergy, thus limiting the generalizability of the results to community settings. There is currently no research examining the natural history of peanut allergy at the population-level, irrespective of SPT wheal size and SIgE level.

\subsection{Egg Allergy}

Eleven studies reported on the use of SPT and SIgE during the course of follow-up, and its association with persistent or resolved egg allergy (Table 2). Three studies did not find any significant association between SPT or SIgE and prognosis of egg allergy [12,39,41]. 
Table 2. Studies reporting on SPT and SIgE and the prognosis of EGG allergy.

\begin{tabular}{|c|c|c|c|c|c|c|c|c|c|}
\hline Author & $\mathbf{N}$ & Study design & $\begin{array}{l}\text { Diagnosis of } \\
\text { food allergy }\end{array}$ & Age $^{1}$ & $\begin{array}{l}\text { Period of } \\
\text { follow-up }\end{array}$ & $\begin{array}{c}\text { Follow-up } \\
\text { diagnosis }\end{array}$ & Tolerance & SPT (mm) & $\operatorname{sIgE}\left(k \mathbf{U}_{\mathbf{A}} / \mathbf{L}\right)$ \\
\hline \multirow{6}{*}{$\begin{array}{l}\text { Montesinos et al } \\
2010 \text { [48] }\end{array}$} & \multirow{6}{*}{42} & \multirow{6}{*}{$\begin{array}{l}\text { Retrospective } \\
\text { follow-up }\end{array}$} & \multirow{6}{*}{$\begin{array}{l}\text { Clinical history } \\
\text { and positive } \\
\text { SPT/sIgE and } \\
\text { OFC }\end{array}$} & \multirow{6}{*}{$\begin{array}{l}15.7 \text { months } \\
\text { (range } \\
8-27.5 \\
\text { months) }\end{array}$} & \multirow{6}{*}{$\begin{array}{c}49 \text { months } \\
\text { (range } 15- \\
118.6 \text { months) }\end{array}$} & \multirow{6}{*}{$\begin{array}{c}\text { OFC annually } \\
\text { unless reaction in } \\
\text { previous } \\
3 \text { months and } \\
\text { positive SPT/sIgE }\end{array}$} & \multirow{6}{*}{$50 \%$} & & $\begin{array}{c}\leq 2 \text { years: } 1.37,96 \% \mathrm{PPV} \\
0.36,66 \% \mathrm{NPV}\end{array}$ \\
\hline & & & & & & & & & $\begin{array}{c}2-3 \text { years: } 1.52,100 \% \text { PPV } \\
0.54,75 \% \mathrm{NPV}\end{array}$ \\
\hline & & & & & & & & & $\begin{array}{c}3-4 \text { years: } 1.35,100 \% \mathrm{PPV} \\
0.36,75 \% \mathrm{NPV}\end{array}$ \\
\hline & & & & & & & & & $4-5$ years: $2.59,100 \%$ PPV \\
\hline & & & & & & & & & $0.96,60 \% \mathrm{NPV}$ \\
\hline & & & & & & & & & $\begin{array}{c}>5 \text { years: } 1.84,100 \% \mathrm{PPV} \\
0.65,100 \% \mathrm{NPV}\end{array}$ \\
\hline $\begin{array}{c}\text { Dieguez et al. } \\
2009[20]\end{array}$ & 157 & $\begin{array}{l}\text { Retrospective } \\
\text { follow-up }\end{array}$ & $\begin{array}{l}\text { Clinical history } \\
\text { and positive SPT } \\
\text { or SIgE, or OFC }\end{array}$ & $\begin{array}{l}2.5 \text { years } \\
\text { (range } 1-16 \\
\text { years) }\end{array}$ & NR & DBPCFC & $36 \%$ & $\begin{array}{c}\geq 7,90 \% \mathrm{PPV} \\
\mathrm{LR}+6.7 \\
\geq 9,96 \% \mathrm{PPV} \\
\mathrm{LR}+12.3\end{array}$ & $\geq 1.590 \% \mathrm{PPV}, \mathrm{LR}+5.5$ \\
\hline Kim 2009 [41] & 106 & Retrospective & $\operatorname{sIgE}>2$ & $<2$ years & $\begin{array}{c}\text { Median } \\
49 \text { months } \\
\text { (range 23-132 } \\
\text { months) }\end{array}$ & $\begin{array}{c}\text { Home challenge } \\
\text { test if } \operatorname{sigE}<1.5 \\
\text { or accidental } \\
\text { ingestion without } \\
\text { reaction }\end{array}$ & $58 \%$ & & $\begin{array}{c}\text { Peak sIgE not predictive of } \\
\text { outcome }\end{array}$ \\
\hline Mudd 2009 [39] & 38 & $\begin{array}{l}\text { Retrospective } \\
\text { chart review }\end{array}$ & OFC & 5 years & 2.8 years & $\begin{array}{c}\text { OFC } \\
\text { when clinically } \\
\text { indicated }\end{array}$ & $47 \%$ & & Not predictive of tolerance \\
\hline $\begin{array}{c}\text { Savage et al. } \\
2007 \text { [22] }\end{array}$ & 881 & $\begin{array}{l}\text { Retrospective } \\
\text { chart review }\end{array}$ & $\begin{array}{l}\text { Clinical history } \\
\text { or sIgE }>2 \\
\text { and no known } \\
\text { exposure }\end{array}$ & $\begin{array}{l}14 \text { months } \\
\text { (IQR } 10,23 \\
\text { months) }\end{array}$ & $\begin{array}{c}\text { Median } \\
59 \text { months } \\
\text { (range 5-285 } \\
\text { months) }\end{array}$ & $\begin{array}{c}\text { OFC if } \\
\operatorname{sIgE}<2 \mathrm{kU}_{\mathrm{A}} / \mathrm{L}\end{array}$ & $68 \%$ & & $\begin{array}{l}\text { Rate of tolerance inversely } \\
\text { related to peak sIgE. } \\
\text { sIgE }>50 \text { marker for } \\
\text { persistent allergy }\end{array}$ \\
\hline
\end{tabular}


Table 2. Cont.

\begin{tabular}{|c|c|c|c|c|c|c|c|c|c|}
\hline Author & $\mathbf{N}$ & Study design & $\begin{array}{l}\text { Diagnosis of } \\
\text { food allergy }\end{array}$ & Age $^{1}$ & $\begin{array}{l}\text { Period of } \\
\text { follow-up }\end{array}$ & $\begin{array}{c}\text { Follow-up } \\
\text { diagnosis }\end{array}$ & Tolerance & SPT (mm) & $\operatorname{sIgE}\left(k U_{A} / L\right)$ \\
\hline $\begin{array}{c}\text { Perry et al. } \\
2004[14]\end{array}$ & 138 & $\begin{array}{l}\text { Retrospective } \\
\text { chart review }\end{array}$ & $\begin{array}{l}\text { Clinical history } \\
\text { or SPT/sIgE }\end{array}$ & NR & NR & $\begin{array}{c}\text { OFC when } \\
\text { clinically } \\
\text { indicated or } \\
\text { sIgE }<95 \% \text { PPV }\end{array}$ & $57 \%$ & & $\begin{array}{c}\operatorname{sIgE}<250 \% \text { probability of } \\
\text { tolerance }\end{array}$ \\
\hline $\begin{array}{l}\text { Shek et al. } \\
2004 \text { [33] }\end{array}$ & 88 & Retrospective & DBPCFC & $\begin{array}{l}6 \text { months- } \\
17 \text { years }\end{array}$ & $\begin{array}{l}\text { Up to } \\
10 \text { years }\end{array}$ & DBPCFC & $32 \%$ & & $\begin{array}{l}\text { sIgE decrease by } 50 \% \text { in } \\
12 \text { months: } 0.52 \text { probability } \\
\text { of tolerance } \\
\text { sIgE decrease by } 90 \% \text { in } \\
12 \text { months: } 0.78 \text { probability } \\
\text { of tolerance }\end{array}$ \\
\hline $\begin{array}{l}\text { Boyano-martinez } \\
\text { et al. 2002 [49] }\end{array}$ & 59 & Prospective & $\begin{array}{l}\text { OFC }(\mathrm{n}=35) \text { or } \\
\text { recent reaction } \\
\text { and positive } \\
\text { SIgE }\end{array}$ & $<2$ years & $\begin{array}{l}\text { Median } \\
32 \text { months }\end{array}$ & $\begin{array}{l}\text { OFC every } 1-3 \\
\text { years depending } \\
\text { on previous } \\
\text { symptoms }\end{array}$ & $59 \%$ & $\begin{array}{c}\text { SPT }<6 \\
\text { increased } \\
\text { likelihood }(\mathrm{HR}) \\
\text { of tolerance by } \\
3.74(95 \% \mathrm{CI} \\
1.60-8.74) .\end{array}$ & $\begin{array}{l}\text { sIgE predicted tolerance } \\
\text { only in children with } \\
\text { cutaneous symptoms }\end{array}$ \\
\hline $\begin{array}{c}\text { Crespo et al. } \\
1994[43]\end{array}$ & 40 & & OFC & 1 year & 2.5 years & OFC & $38 \%$ & & $\operatorname{sIgE} \geq 1.2 \mathrm{ku}_{\mathrm{A}} / \mathrm{L} 92 \% \mathrm{PPV}$ \\
\hline $\begin{array}{c}\text { Sampson } 1989 \\
{[12]}\end{array}$ & 59 & Retrospective & DBPCFC & $\begin{array}{l}7.9 \text { years } \\
\text { (range } 3-18 \\
\text { years) }\end{array}$ & $1-3$ years & $\begin{array}{l}\text { DBPCFC or } \\
\text { accidental } \\
\text { ingestion }\end{array}$ & $24 \%$ & $\begin{array}{l}\text { Not predictive of } \\
\text { tolerance }\end{array}$ & \\
\hline Ford 1982 [47] & 25 & & DBPCFC & $\begin{array}{l}17 \text { months } \\
\text { (range } \\
6 \text { months- } \\
10 \text { years) }\end{array}$ & $2-2.5$ years & OFC & $44 \%$ & $\begin{array}{l}\text { Decreased in } \\
\text { resolved allergy }\end{array}$ & \\
\hline
\end{tabular}

NR: not reported; IQR: interquartile range; HR: hazard ratio; ${ }^{1}$ Age at diagnosis or entry into study; reported as mean or median (range). 
Boyano Martinez conducted the only prospective study on the natural history of egg allergy. Fifty-nine children under 2 years of age were recruited from a paediatric allergy clinic, with a previous diagnosis of egg allergy on the basis of OFC or meeting several criteria associated with a high probability of reaction (e.g., positive sIgE, recent reaction, previous anaphylaxis). Children were reviewed every 6-12 months depending on their age and offered OFC every 1-3 years depending on their previous reactions to egg. During follow-up, egg allergy resolved in 59\%. SPT $<6 \mathrm{~mm}$ at follow-up increased the likelihood (hazard ratio (HR)) of tolerance by 3.74 (95\% CI 1.60-8.74). Whilst it is useful to know that SPT below a particular level increases the odds of tolerance, it is less useful in a clinical setting without the accompanying sensitivity, specificity and positive and negative predictive values, which were not reported in this study. Magnitude of sIgE was also associated with tolerance, however only in children with cutaneous symptoms at the time of diagnosis. For every 0.1 unit decrease in SIgE, the likelihood (HR) of tolerance increased by 1.17 (95\% CI 1.05-1.30). No such association was observed in children with respiratory or gastrointestinal symptoms on their index reaction to egg [49].

Thresholds of sIgE with high PPV to persistent egg allergy were reported in three studies and ranged from $\geq 1.2$ to $2.59 \mathrm{kU}_{\mathrm{A}} / \mathrm{L}[20,43,48]$. Montesinos et al. conducted a retrospective follow-up study of 42 children, (mean age 15.7 months, range 8-27.5) with a previous diagnosis of egg allergy confirmed by OFC and all children were rechallenged annually unless they had had a reaction within the previous 3 months. Although not explicitly stated, from the available data, it appears that OFC at follow-up was undertaken irrespective of sIgE. The authors reported thresholds with $\geq 95 \%$ PPV to persistent egg allergy for different periods of follow-up which ranged from $<2$ to $>5$ years. $\operatorname{sigE}$ thresholds with $95 \%$ PPV ranged from $\geq 1.35-2.59 \mathrm{kU}_{\mathrm{A}} / \mathrm{L}$. NPVs to predict resolved egg allergy were also reported, but only reached high probability $(100 \% \mathrm{NPV})$ at $\geq 5$ years of follow-up when $\mathrm{SIgE}<0.65 \mathrm{kU}_{\mathrm{A}} / \mathrm{L}$ [48]. Crespo et al. reported a similar threshold of $\operatorname{sIgE} \geq 1.2 \mathrm{kU}_{\mathrm{A}} / \mathrm{L}$ to have $92 \%$ PPV to persistent egg allergy after 2.5 years of follow-up [43].

Diguez et al. conducted a cross-sectional study on 157 children with a previous diagnosis of egg allergy on the basis of clinical history and positive SPT/sIgE, or OFC when necessary. Persistence or tolerance was determined by DBPCFC in all participants. SPT $\geq 7 \mathrm{~mm}$ and $\operatorname{sigE} \geq 1.5 \mathrm{kU}_{\mathrm{A}} / \mathrm{L}$ at follow-up had $90 \%$ PPV to persistent egg allergy. This is one of the few studies to also report the positive likelihood ratio which was 6.7 and 5.5 respectively, for the aforementioned SPT and $\operatorname{sigE}$ thresholds [20]. PPVs are dependent upon the underlying prevalence of disease, unlike the likelihood ratio which is derived from the sensitivity and specificity. The likelihood ratio allows the clinician to transfer results from one setting to their own, and develop the probability of disease for each patient depending on their pre-test probability of disease [35]. These three studies were recruited from tertiary allergy clinics where between $36 \%$ and $50 \%$ of egg allergy resolved, and may not be applicable in settings where the prevalence of egg allergy is lower, or rate of resolution is higher, for example in a community setting.

Two studies reported on whether peak sIgE was associated with the development of tolerance to egg in egg allergic patients, but with differing results. Savage et al. conducted a large, retrospective chart review of 881 children with egg allergy, diagnosed by clinical history or $\operatorname{sigE}>2 \mathrm{kU} / \mathrm{L}$ with no known tolerance to egg. As for Ho et al.'s peanut allergy study [10], assessment of tolerance to egg by OFC was only activated when the IgE fell below a certain threshold (i.e., when $\operatorname{sigE}<2 \mathrm{kU}_{\mathrm{A}} / \mathrm{L}$ ) or 
following uneventful accidental exposure. The authors found that sIgE decreased in both children with persistent and resolved egg allergy, however the rate of decrease was sharper in those with resolved allergy. Children with persistent egg allergy had larger sIgE levels in the first two years of life compared to children with transient allergy and this difference was maintained through to 18 years. Peak sIgE was inversely related to the probability of tolerance, i.e., the higher the peak sIgE, the less likely that the child would outgrow egg allergy. Children with peak $\operatorname{sigE}<2 \mathrm{kU} / \mathrm{L}$ had the fastest rates of tolerance development. Although this study is very important because of the large sample size, it is limited by biasing towards persistent allergic disease as participants were generally offered OFC when $\mathrm{sIgE}$ fell below $2 \mathrm{kU}_{\mathrm{A}} / \mathrm{L}$ [22]. In contrast, in a smaller retrospective study of 106 children with egg allergy defined as $\operatorname{sIgE} \geq 2 \mathrm{kU}_{\mathrm{A}} / \mathrm{L}$, peak $\operatorname{sIgE}$ was not associated with persistent allergy. A limitation of this study was that egg allergy or tolerance was not confirmed by hospital-based OFC at diagnosis or follow-up. Tolerance was confirmed by home challenge test only when $\operatorname{sIgE}<1.5 \mathrm{kU}_{\mathrm{A}} / \mathrm{L}[41]$.

Two studies reported SPT or sIgE levels at follow-up that were associated with a child's probability of having developed tolerance to egg. The study by Perry et al. (previously described for peanut allergy) reported that $\operatorname{sIgE}<2 \mathrm{kU}_{\mathrm{A}} / \mathrm{L}$ was associated with a $50 \%$ probability of tolerance [22]. Shek et al. reported results from a retrospective study of 88 children and found that the degree of change in decrease in SIgE was associated with tolerance in children who were under 4 years of age at the time of their first OFC, but the association was weaker in children over 4 years of age. In children less than 4 years of age, a $50 \%$ decrease in sIgE in any 12 month period was associated with $52 \%$ probability of tolerance, whilst a $90 \%$ decrease was associated with a $78 \%$ probability of tolerance [33].

There is increasing evidence to suggest that $60 \%-80 \%$ of children allergic to raw egg are able to tolerate egg in baked foods, and furthermore, tolerance to baked egg is predictive of the resolution of egg allergy [50-52]. Improvement in the performance of 95\% PPVs to the resolution of egg allergy may be achieved by stratifying upon egg allergy phenotype, i.e., raw and baked egg allergic versus raw egg allergic, baked egg tolerant.

Several studies reported on the use of SPT and SIgE to predict the persistence or resolution of egg allergy. Three studies supported the use of $\operatorname{sgE}$ between 1.2 to $2.59 \mathrm{kU}_{\mathrm{A}} / \mathrm{L}$ at follow-up as a marker for persistent egg allergy $[20,43,48]$, whilst others suggested that low or decreasing sIgE was predictive of resolved egg allergy. Only one study was prospective, and no studies were recruited from a population-based setting. There is a need for prospective, population-based studies using the gold standard OFC in all participants, irrespective of SPT and SIgE, to examine the predictive value of these tests to the prognosis of egg allergy.

\subsection{Milk Allergy}

Thirteen studies reported on the use of SPT and SIgE during follow-up, and its association with persistent or resolved milk allergy (Table 3). Two studies did not find any significant association between SPT or sIgE and prognosis of milk allergy; these studies both had small sample sizes $(<30$ participants) $[12,42]$. 
Table 3. Studies reporting on SIgE as a predictor of the prognosis of MILK allergy.

\begin{tabular}{|c|c|c|c|c|c|c|c|c|c|}
\hline Author & $\mathbf{N}$ & Study design & Diagnosis & Age $^{1}$ & $\begin{array}{l}\text { Period of } \\
\text { follow-up }\end{array}$ & $\begin{array}{c}\text { Follow-up } \\
\text { diagnosis }\end{array}$ & Tolerance & SPT (mm) & $\operatorname{sIgE}\left(k U_{A} / L\right)$ \\
\hline $\begin{array}{c}\text { Yavuz } \\
2013 \text { [53] }\end{array}$ & 148 & Retrospective & $\begin{array}{l}\text { Clinical history, } \\
\text { positive SPT/sIgE } \\
\text { and either positive } \\
\text { OFC or history of } \\
\text { anaphylaxis }\end{array}$ & $\begin{array}{l}1.6 \text { years (IQR } \\
0.9-3.1 \text { years) }\end{array}$ & $\begin{array}{c}3.5 \text { years } \\
\text { (IQR } 1.8-5.2 \\
\text { years) }\end{array}$ & $\begin{array}{l}\text { OFC if sIgE low } \\
\text { and no recent } \\
\text { reaction }\end{array}$ & $45 \%$ & & $\begin{array}{c}\text { Age-specific } 95 \% \text { PPVs } \\
\text { to persistent allergy } \\
<1 \text { years: } 1.4 \\
<2 \text { years: } 9.3 \\
<4 \text { years: } 9.4 \\
<6 \text { years: } 11 \\
\text { All: } 11\end{array}$ \\
\hline $\begin{array}{c}\text { Suh } 2011 \\
{[36]}\end{array}$ & 115 & Retrospective & $\begin{array}{l}\text { Clinical history } \\
\text { and } \operatorname{sIgE}>0.35 \text {; } \\
\quad \text { or } \operatorname{sIgE}>5\end{array}$ & $<24$ months & $\begin{array}{c}\text { Mean } 47 \\
\text { months } \\
\text { (range 24-114 } \\
\text { months) }\end{array}$ & $\begin{array}{l}\text { OFC or home } \\
\text { introduction }\end{array}$ & $41 \%$ & & $\begin{array}{l}\text { Higher peak sIgE in first } \\
24 \text { months reduced } \\
\text { probability of tolerance. }\end{array}$ \\
\hline $\begin{array}{l}\text { Savilahti } \\
2010 \text { [46] }\end{array}$ & 83 & $\begin{array}{l}\text { Prospective } \\
\text { birth cohort } \\
(\mathrm{n}=6,209)\end{array}$ & $\begin{array}{l}\text { Open OFC and } \\
\text { SPT } \geq 3 \mathrm{~mm} \\
\text { or } \mathrm{sIgE} \geq 0.7\end{array}$ & 7 months & Up to 8 years & $\begin{array}{l}\text { OFC or home } \\
\text { introduction }\end{array}$ & $78 \%$ & & $\begin{array}{l}\text { sIgE higher in those } \\
\text { with persistent allergy }\end{array}$ \\
\hline $\begin{array}{c}\text { Santos } \\
2010[54]\end{array}$ & 66 & Retrospective & $\begin{array}{l}\text { OFC and SPT } \\
\text { or } \operatorname{sigE}\end{array}$ & NR & Median 7 years & $\begin{array}{l}\text { OFC if SPT or SIgE } \\
\text { decreased and no } \\
\text { recent reaction }\end{array}$ & $50 \%$ & $\begin{array}{c}\text { Peak }>10 \mathrm{~mm} \\
\text { reduced the } \\
\text { likelihood of } \\
\text { tolerance (HR } \\
0.38,95 \% \mathrm{CI} \\
0.14-0.99)\end{array}$ & $\begin{array}{l}\text { Higher maximum sIgE } \\
\text { over time reduced the } \\
\text { likelihood of tolerance }\end{array}$ \\
\hline $\begin{array}{l}\text { Martorell } \\
2008 \text { [16] }\end{array}$ & 170 & Prospective & $\begin{array}{l}\text { Clinical history } \\
\text { or OFC, and SPT } \\
\text { or sIgE }\end{array}$ & $\begin{array}{c}5.4 \text { months } \\
\text { (1-12 months) }\end{array}$ & $\begin{array}{l}\text { Up to } 4 \text { years } \\
\text { of age }\end{array}$ & $\begin{array}{l}\text { OFC if no reaction } \\
\text { in previous } \\
3 \text { months }\end{array}$ & $82 \%$ & & $\begin{array}{l}\text { Age-specific } 95 \% \text { PPVs } \\
\text { to persistent allergy } \\
12 \text { months: } 5.86 \\
18 \text { months: } 9.79 \\
24 \text { months: } 25.7 \\
36 \text { months: } 7.38 \\
48 \text { months: } 5.0\end{array}$ \\
\hline
\end{tabular}


Table 3. Cont.

\begin{tabular}{|c|c|c|c|c|c|c|c|c|c|}
\hline Author & $\mathbf{N}$ & Study design & Diagnosis & Age $^{1}$ & $\begin{array}{l}\text { Period of } \\
\text { follow-up }\end{array}$ & $\begin{array}{l}\text { Follow-up } \\
\text { diagnosis }\end{array}$ & Tolerance & SPT (mm) & $\operatorname{sIgE}\left(k U_{A} / L\right)$ \\
\hline $\begin{array}{l}\text { Skripak } \\
2007[23]\end{array}$ & 807 & $\begin{array}{l}\text { Retrospective } \\
\text { review }\end{array}$ & $\begin{array}{l}\text { Clinical history } \\
\text { plus OFC or } \\
\text { elimination diet }\end{array}$ & $\begin{array}{c}13 \text { months } \\
\text { (range } 1-209 \\
\text { months) }\end{array}$ & $\begin{array}{l}\text { Median } \\
54 \text { months }\end{array}$ & $\begin{array}{l}\mathrm{OFC} \text { if } \operatorname{sIgE}<2 ; \text { or } \\
\text { home introduction }\end{array}$ & $15 \%$ & & $\begin{array}{l}\text { Higher peak sIgE } \\
\text { reduced probability } \\
\text { of tolerance. }\end{array}$ \\
\hline $\begin{array}{l}\text { Saarinen } \\
2005[17]\end{array}$ & 86 & $\begin{array}{l}\text { Prospective } \\
\text { birth cohort }\end{array}$ & $\begin{array}{l}\text { Elimination } \\
\text { challenge test }\end{array}$ & 7 months & Up to 8 years & $\begin{array}{c}\text { Home challenge test } \\
\text { or OFC }\end{array}$ & $85 \%$ & $\begin{array}{l}\text { SPT } 12 \text { months } \\
\text { after diagnosis: } \\
\geq 7 \text { mm AUC } 0.84\end{array}$ & \\
\hline $\begin{array}{c}\text { Perry } 2004 \\
{[14]}\end{array}$ & 166 & $\begin{array}{l}\text { Retrospective } \\
\text { chart review }\end{array}$ & $\begin{array}{l}\text { Clinical history or } \\
\text { SPT/sIgE }\end{array}$ & NR & NR & $\begin{array}{l}\text { OFC if clinically } \\
\text { indicated }\end{array}$ & $45 \%$ & & $\begin{array}{c}<250 \% \text { probability of } \\
\text { tolerance }\end{array}$ \\
\hline $\begin{array}{c}\text { Garcia- } \\
\text { Ara } 2004 \\
{[44]}\end{array}$ & 66 & Prospective & $\mathrm{OFC}$ & $\begin{array}{l}4.8 \text { months } \\
\text { (range } 1-11 \\
\text { months) }\end{array}$ & $\begin{array}{c}\text { Mean } \\
\text { 32.9 months } \\
\text { (range 9-99 } \\
\text { months) }\end{array}$ & OFC & $68 \%$ & & $\begin{array}{c}\text { Age-specific } 95 \% \text { PPVs } \\
\text { to persistent allergy } \\
\text { 13-18months: } 2.7 \\
\text { 19-24months: } 9 \\
\text { 26-36months: } 24\end{array}$ \\
\hline $\begin{array}{c}\text { Shek } 2004 \\
\text { [33] }\end{array}$ & 49 & Retrospective & DBPCFC & 34 months & Up to 10 years & DBPCFC & $33 \%$ & & $\begin{array}{l}\text { sIgE decrease of } 50 \% \text { in } \\
12 \text { months }-0.31 \\
\text { probability of tolerance } \\
\text { sIgE decrease of } 90 \% \text { in } \\
12 \text { months }-0.66 \\
\text { probability of tolerance }\end{array}$ \\
\hline $\begin{array}{l}\text { Hill } 1993 \\
\text { [45] }\end{array}$ & 69 & Prospective & OFC or SPT & 20 months & $\begin{array}{l}\text { Median } \\
24 \text { months }\end{array}$ & $\begin{array}{c}\text { Home introduction } \\
\text { or OFC at } 5 \text { years } \\
\text { of age }\end{array}$ & $22 \%$ & & $\begin{array}{l}\text { Lower in } \\
\text { transient allergy }\end{array}$ \\
\hline $\begin{array}{c}\text { James } \\
1992[42]\end{array}$ & 29 & & DBPCFC & $\begin{array}{c}7 \text { years } \\
\text { (range } 3-14 \\
\text { years) }\end{array}$ & $\begin{array}{l}\text { Median } \\
3 \text { years }\end{array}$ & DBPCFC & $38 \%$ & $\begin{array}{l}\text { Not predictive } \\
\text { of tolerance }\end{array}$ & $\begin{array}{l}\text { Not predictive } \\
\text { of tolerance }\end{array}$ \\
\hline $\begin{array}{l}\text { Sampson } \\
1989[12]\end{array}$ & 21 & Retrospective & DBPCFC & $\begin{array}{c}7.9 \text { years } \\
\text { (range } 3-18 \\
\text { years) } \\
\end{array}$ & $1-3$ years & $\begin{array}{c}\text { DBPCFC or } \\
\text { accidental ingestion }\end{array}$ & $19 \%$ & $\begin{array}{l}\text { Not predictive } \\
\text { of tolerance }\end{array}$ & \\
\hline
\end{tabular}

NR: not reported; HR: hazards ratio; ${ }^{1}$ Age at diagnosis or entry into study; reported as mean or median (range). 
There were three studies that reported milk-sIgE thresholds with 95\% PPV to persistent milk allergy which stratified the 95\% PPVs by age of the children during follow-up. Yavuz et al. conducted a retrospective study of 148 children diagnosed with milk allergy on the basis of clinical history, positive SPT or SIgE and either a positive OFC or history of anaphylaxis. Children were offered an OFC to test for tolerance when it was considered they had a 50\% probability of tolerance, based on lack of recent reactions or low sIgE levels. sIgE thresholds with $95 \%$ PPV to persistent milk allergy were $1.4 \mathrm{kU}_{\mathrm{A}} / \mathrm{L}, 9.3 \mathrm{kU}_{\mathrm{A}} / \mathrm{L}, 9.4 \mathrm{kU}_{\mathrm{A}} / \mathrm{L}$ and $11.0 \mathrm{kU}_{\mathrm{A}} / \mathrm{L}$ for children $<1,<2,<4$, and $<6$ years of age respectively. Specificity was generally high at these thresholds, $89 \%-96 \%$, but sensitivity was modest, $44 \%-90 \%[53]$.

In a prospective study by Martorell et al., 170 infants under 12 months diagnosed with milk allergy, on the basis of clinical history or OFC, were offered repeat OFCs periodically over 4 years, with the exception of those who experienced a reaction in the preceding 3 months. The authors reported thresholds with 95\% PPV to persistent milk allergy for different ages between 12 and 48 months, which differed substantially by age. Thresholds with 95\% PPV to persistent milk allergy were $5.86 \mathrm{kU}_{\mathrm{A}} / \mathrm{L}, 25.7 \mathrm{kU}_{\mathrm{A}} / \mathrm{L}, 7.38 \mathrm{kU}_{\mathrm{A}} / \mathrm{L}$ and $5.0 \mathrm{kU}_{\mathrm{A}} / \mathrm{L}$ at $12,24,36$ and 48 months respectively [16].

Another study also reported that $95 \%$ PPVs to milk allergy persistence varied by age. In this study 66 infants aged under 12 months were recruited and milk allergy was confirmed by OFC in all participants at diagnosis and review, with the exception of those who had a reaction in the preceding 3 months. sIgE thresholds with 95\% PPV to persistent milk allergy were $2.7 \mathrm{kU} / \mathrm{L}, 9.0 \mathrm{kU} / \mathrm{L}$ and $24.0 \mathrm{kU}_{\mathrm{A}} / \mathrm{L}$ at 13-18, 19-24 and 25-36 months respectively [44]. This supports the argument for the necessity of age-specific PPVs to predict the course of food allergy, however, even when restricted to similar ages of children, the 95\% PPVs differ substantially between studies. This issue is common among studies reporting 95\% PPVs at the diagnosis of food allergy and is largely due to differences in populations, study designs and prevalence of disease [31].

Several studies recommended optimal SPT or sIgE cut-offs from ROC analysis or thresholds with a hazard or odds ratio that indicate it was predictive of the outcome [14,17,36,54]. Often however, the sensitivity and specificity at the threshold was not reported, so although they may be useful to guide clinician's decision making as to the likelihood of a reaction, these thresholds should not be used as a proxy for OFC as the number of false positives and negatives is not specified. Three studies reported that the higher the peak sIgE, the lower one's probability of developing tolerance $[23,36,54]$ and one study reported the same association with SPT [54]. Shek et al. reported that a 50\% or $90 \%$ decrease in sIgE within a 12-month period was associated with a probability of achieving tolerance by 0.31 and 0.66 , respectively [33].

There was one recently published study that did not meet the inclusion criteria because it examined SPT and sIgE at diagnosis, rather than at follow-up, to predict the course of milk allergy, but it is worth noting here. Wood et al. published results from an observational study of 293 children with milk allergy who were aged between 3 and 15 months at enrolment. The majority of children were followed-up until at least 4 years of age where tolerance was confirmed by either OFC or successful home introduction. Using proportional hazards regression, the authors found that baseline SPT, sIgE and severity of atopic dermatitis was predictive of resolved milk allergy. Although no specific diagnostic threshold was reported, the authors developed an online calculator that produced a graph of probability of resolution of milk allergy over time, based on SPT, SIgE and eczema at diagnosis [37]. 
This is a useful tool to individualize patient counseling and could be used to address parent questions relating to the probability and timing of resolution. It would be useful to replicate this for other foods. Other research teams have developed calculators for the diagnosis of food allergy using several routinely available clinical factors, including SPT, sIgE, symptoms, sex and age. Similar tools may be useful for predicting the development of tolerance [55].

Two studies were derived from birth cohorts and represent population-derived data with the full spectrum of disease, rather than only the severe end of the spectrum that are likely to dominate tertiary clinic samples [17,46]. These studies reported higher rates of resolution, but unfortunately did not present sufficient information on the predictive value of SPT or SIgE to resolution of milk allergy.

\section{Summary and Future Directions}

It is not currently clear why some children outgrow their food allergy and others do not. OFCs remain the gold standard for diagnosis of food allergy, as well as determining tolerance, yet are resource consuming and can result in severe reactions. Therefore, reliable criteria as to when to conduct a repeat OFC for tolerance detection or defer because of a high likelihood of persistent allergy are needed in clinical practice. Whilst there is modest evidence that SPT and sIgE may predict which children have a high probability of persistent food allergy, there is not a sufficient body of evidence to support the use of a particular threshold as a marker of resolved or persistent allergy and to avoid unnecessary OFC. Low or decreasing SPT and SIgE was associated with the development of tolerance, however there is little data to inform whether persistently elevated SPT or sIgE really predicts the persistence of allergy, since many studies assumed that those with elevated results were still allergic. The limitation of using SIgE for assessment of resolution of food allergy is the fact that to date no study has systematically assessed whether 95\% PPV developed for food allergy diagnosis are also appropriate for assessment of resolution. The only way to systematically assess resolution would be to regularly challenge consecutive children irrespective of SPT or sIgE. Currently challenges are usually only considered when SPT/SIgE decrease in size or become negative and therefore are biased to the persistence of food allergy. Since most studies assessing SPT/sIgE for resolution undertake retrospective analysis of databases and do not provide the predetermined clinical criteria for ordering tolerance challenges the literature in this area is severely deficient.

This review has highlighted several limitations of previous research, which unfortunately may limit our ability to make any clinical recommendations. These include the absence of systematic application of the gold standard test, (OFC) to diagnose food allergy or tolerance irrespective of wheal size in order to generate non-biased estimates, biased participation in retrospective audits and lack of systematic protocols for triggering re-challenges. Future studies should ensure that they have taken appropriate measures to overcome these. Importantly to date, very few studies have undertaken follow-up OFC irrespective of SPT wheal size. Therefore, currently available data is likely to be significantly biased to the persistence of allergic disease and overestimate the PPV. This significant gap in the literature is important not just from a clinical prognostic perspective with regards to what we tell our patients, but also informs predicted outcomes for OFC which may be incorrectly assuming lower rates of resolution. Oral immunotherapy trials, which do undertake follow-up OFC irrespective of wheal size, are likely to offer important natural history information in control arms. Currently there 
are limited numbers of participants in placebo arms of RCTs, yet this data could be used for the systematic development of PPVs for food allergy resolution [56,57]. Data from these studies and in progress cohort studies such as the HealthNuts study which is capturing follow-up OFC data in all sensitised children at age 4 (with food allergy status initially determined by OFC at 12 months for all children) irrespective of SPT wheal size will provide a source of invaluable prognostic data [58].

There are several potential improvements for the prediction of tolerance that are yet to be sufficiently investigated. Whilst it is established that there are certain risk factors for the development of food allergy, for example eczema and family history, it is not yet clear whether the presence or absence of these risk factors are associated with the persistence or resolution of food allergy. Although several studies have examined these, results are largely inconsistent $[22,41,49,54,59,60]$. However, if these factors are demonstrated to offer predictive value to the course of food allergy, the sensitivity and specificity of SPT and SIgE may be further improved by stratifying upon these factors. Likewise, stratifying upon immunological factors that predict the risk of food allergy, e.g., serum cytokine profiles, may improve the predictive value of SPT and SIgE [61].

Component resolved diagnostics (e.g., sIgE to sub-fractions of major food allergens, for example Ara $\mathrm{H} 2$ in peanuts), have been shown to improve the diagnosis of food allergy because they have higher sensitivity and specificity than peanut-sIgE alone [62]. Likewise they may play a significant role in predicting the likelihood of persistent or resolved peanut allergy. Individual cow's milk allergens, particularly casein and lactalbumin, were shown to be good prognostic markers to persistent cow's milk allergy, however their efficiency was comparable to milk-sIgE and at this stage, they are not recommend for daily practice due to increased laboratory costs with little additional benefit [44,63]. With regards to egg allergy, ovomucoid, which is one of the major allergens, may also be useful in the identification of children with persistent egg allergy. Children with persistent egg allergy tended to have higher concentrations of IgE antibodies to ovomucoid compared to children with transient egg allergy $[64,65]$.

Another in vitro test that is being explored for the prediction of food allergy is the basophil activation test (BAT). Studies on the utility of BAT to predict food allergy and the development of tolerance are limited in number in comparison to SPT and sIgE. Initial studies have demonstrated moderate to high sensitivity and specificity of BAT to both the diagnosis of food allergy, and in particular, the resolution of milk allergy [66-68]. At this stage, BAT may be useful as a complement to conventional SPT and SIgE tests, and warrants further research.

Researchers are identifying new information about the genetic predisposition to food allergy and it is possible that genetics or gene-environment interactions may also play a role in the development of tolerance [69]. In the future, genotyping may assist in identifying children more likely to develop tolerance. In the study by Yavuz et al. (previously described), they found that the development of tolerance to cow's milk was significantly higher in children with GG genotype at certain SNPs on STAT6, compared to AA + AG genotype, although there was no difference between their initial and peak sIgE levels between these two groups [53]. Nevertheless, this research is amongst the first to attempt to identify genetic predictors of tolerance development, of which there may be multiple. When used in conjunction with SPT, sIgE and possibly component resolved diagnostics, genetic risk stratification may improve the management of childhood food allergy. 


\section{Conclusions}

In this study, we reviewed papers that examined the association between SPT or SIgE and the resolution of food allergy. Despite methodological and population differences, collectively these studies confirm that food allergy is a transient condition for some children and that SPT and $\operatorname{sigE}$ evolve with the progression of the disease. Most studies reported thresholds that increased a patient's probability of tolerance but the data on persistence is biased. Previous research is hampered by absence of OFC to diagnose food allergy or tolerance, highly-selective clinic samples, biased participation in retrospective studies, and lack of systematic protocols for triggering re-challenges There is a need for population-based food allergy studies, using OFC irrespective of SPT and SIgE to confirm all cases of food allergy at baseline and follow-up, to examine the ability of SPT and SIgE to predict the course of food allergy. This information will assist the allergist to determine optimal periods of follow-up, facilitate the decision of when to conduct future OFC to test for tolerance and avoid unnecessary OFC.

\section{Conflicts of Interest}

The authors declare no conflict of interest.

\section{References}

1. Burr, M.L.; Merrett, T.G.; Dunstan, F.D.; Maguire, M.J. The development of allergy in high-risk children. Clin. Exp. Allergy 1997, 27, 1247-1253.

2. Liu, A.H.; Jaramillo, R.; Sicherer, S.H.; Wood, R.A.; Bock, S.A.; Burks, A.W.; Massing, M.; Cohn, R.D.; Zeldin, D.C. National prevalence and risk factors for food allergy and relationship to asthma: Results from the National Health and Nutrition Examination Survey 2005-2006. J. Allergy Clin. Immunol. 2010, 126, 798-806.

3. Rhodes, H.L.; Sporik, R.; Thomas, P.; Holgate, S.T.; Cogswell, J.J. Early life risk factors for adult asthma: A birth cohort study of subjects at risk. J. Allergy Clin. Immunol. 2001, 108, 720-725.

4. Tariq, S.M.; Matthews, S.M.; Hakim, E.A.; Arshad, S.H. Egg allergy in infancy predicts respiratory allergic disease by 4 years of age. Pediatr. Allergy Immunol. 2000, 11, 162-167.

5. Du Toit, G.; Santos, A.; Roberts, G.; Fox, A.T.; Smith, P.; Lack, G. The diagnosis of IgE-mediated food allergy in childhood. Pediatr. Allergy Immunol. 2009, 20, 309-319.

6. Sicherer, S.H. Epidemiology of food allergy. J. Allergy Clin. Immunol. 2011, 127, 594-602.

7. Chafen, J.J.; Newberry, S.J.; Riedl, M.A.; Bravata, D.M.; Maglione, M.; Suttorp, M.J.; Sundaram, V.; Paige, N.M.; Towfigh, A.; Hulley, B.J.; et al. Diagnosing and managing common food allergies: A systematic review. J. Am. Med. Assoc. 2010, 303, 1848-1856.

8. Osborne, N.J.; Koplin, J.J.; Martin, P.E.; Gurrin, L.C.; Lowe, A.J.; Matheson, M.C.; Ponsonby, A.L.; Wake, M.; Tang, M.L.; Dharmage, S.C.; et al. Prevalence of challenge-proven IgE-mediated food allergy using population-based sampling and predetermined challenge criteria in infants. J. Allergy Clin. Immunol. 2011, 127, 668-676.

9. Skolnick, H.S.; Conover-Walker, M.K.; Koerner, C.B.; Sampson, H.A.; Burks, W.; Wood, R.A. The natural history of peanut allergy. J. Allergy Clin. Immunol. 2001, 107, 367-374. 
10. Ho, M.H.; Wong, W.H.; Heine, R.G.; Hosking, C.S.; Hill, D.J.; Allen, K.J. Early clinical predictors of remission of peanut allergy in children. J. Allergy Clin. Immunol. 2008, 121, 731-736.

11. Vander Leek, T.K.; Liu, A.H.; Stefanski, K.; Blacker, B.; Bock, S.A. The natural history of peanut allergy in young children and its association with serum peanut-specific IgE. J. Pediatr. 2000, 137, 749-755.

12. Sampson, H.A.; Scanlon, S.M. Natural history of food hypersensitivity in children with atopic dermatitis. J. Pediatr. 1989, 115, 23-27.

13. Fleischer, D.M.; Conover-Walker, M.K.; Christie, L.; Burks, A.W.; Wood, R.A. The natural progression of peanut allergy: Resolution and the possibility of recurrence. J. Allergy Clin. Immunol. 2003, 112, 183-189.

14. Perry, T.T.; Matsui, E.C.; Kay Conover-Walker, M.; Wood, R.A. The relationship of allergen-specific IgE levels and oral food challenge outcome. J. Allergy Clin. Immunol. 2004, $114,144-149$.

15. Nolan, R.C.; Richmond, P.; Prescott, S.L.; Mallon, D.F.; Gong, G.; Franzmann, A.M.; Naidoo, R.; Loh, R.K. Skin prick testing predicts peanut challenge outcome in previously allergic or sensitized children with low serum peanut-specific IgE antibody concentration. Pediatr. Allergy Immunol. 2007, 18, 224-230.

16. Martorell, A.; Garcia Ara, M.C.; Plaza, A.M.; Bone, J.; Nevot, S.; Echeverria, L.; Alonso, E.; Garde, J. The predictive value of specific immunoglobulin E levels in serum for the outcome of the development of tolerance in cow's milk allergy. Allergol. Immunopathol. (Madr.) 2008, 36, 325-330.

17. Saarinen, K.M.; Pelkonen, A.S.; Makela, M.J.; Savilahti, E. Clinical course and prognosis of cow's milk allergy are dependent on milk-specific IgE status. J. Allergy Clin. Immunol. 2005, 116, 869-875.

18. Host, A.; Halken, S. A prospective study of cow milk allergy in Danish infants during the first 3 years of life. Clinical course in relation to clinical and immunological type of hypersensitivity reaction. Allergy 1990, 45, 587-596.

19. Boyano, M.T.; Martin Esteban, M.; Pascual, C.; Ojeda, J.A. Food allergy in children. II. Prognostic factors and long-term development. An. Esp. Pediatr. 1987, 26, 241-245.

20. Dieguez, M.C.; Cerecedo, I.; Muriel, A.; Zamora, J.; Abraira, V.; Camacho, E.; Antón, M.; de la Hoz, B. Utility of diagnostic tests in the follow-up of egg-allergic children. Clin. Exp. Allergy 2009, 39, 1575-1584.

21. Venter, C.; Pereira, B.; Voigt, K.; Grundy, J.; Clayton, C.B.; Higgins, B.; Arshad, S.H.; Dean, T. Prevalence and cumulative incidence of food hypersensitivity in the first 3 years of life. Allergy 2008, 63, 354-359.

22. Savage, J.H.; Matsui, E.C.; Skripak, J.M.; Wood, R.A. The natural history of egg allergy. J. Allergy Clin. Immunol. 2007, 120, 1413-1417.

23. Skripak, J.M.; Matsui, E.C.; Mudd, K.; Wood, R.A. The natural history of IgE-mediated cow's milk allergy. J. Allergy Clin. Immunol. 2007, 120, 1172-1177.

24. Boyano Martinez, T.; Garcia-Ara, C.; Diaz-Pena, J.M.; Munoz, F.M.; Garcia Sanchez, G.; Esteban, M.M. Validity of specific IgE antibodies in children with egg allergy. Clin. Exp. Allergy 2001, 31, 1464-1469. 
25. Celik-Bilgil, S.; Mehl, A.; Verstege, A.; Staden, U.; Nocon, M.; Beyer, K.; Niggemann, B. The predictive value of specific immunoglobulin E levels in serum for the outcome of oral food challenges. Clin. Exp. Allergy 2005, 35, 268-273.

26. Monti, G.; Muratore, M.C.; Peltran, A.; Bonfante, G.; Silvestro, L.; Oggero, R.; Mussa, G.C. High incidence of adverse reactions to egg challenge on first known exposure in young atopic dermatitis children: Predictive value of skin prick test and radioallergosorbent test to egg proteins. Clin. Exp. Allergy 2002, 32, 1515-1519.

27. Roberts, G.; Lack, G. Diagnosing peanut allergy with skin prick and specific IgE testing. J. Allergy Clin. Immunol. 2005, 115, 1291-1296.

28. Sampson, H.A.; Ho, D.G. Relationship between food-specific IgE concentrations and the risk of positive food challenges in children and adolescents. J. Allergy Clin. Immunol. 1997, 100, 444-451.

29. Sporik, R.; Hill, D.J.; Hosking, C.S. Specificity of allergen skin testing in predicting positive open food challenges to milk, egg and peanut in children. Clin. Exp. Allergy 2000, 30, 1540-1546.

30. Verstege, A.; Mehl, A.; Rolinck-Werninghaus, C.; Staden, U.; Nocon, M.; Beyer, K.; Niggemann, B. The predictive value of the skin prick test weal size for the outcome of oral food challenges. Clin. Exp. Allergy 2005, 35, 1220-1226.

31. Peters, R.L.; Gurrin, L.C.; Allen, K.J. The predictive value of skin prick testing for challengeproven food allergy: A systematic review. Pediatr. Allergy Immunol. 2012, 23, 347-352.

32. Clark, A.; Islam, S.; King, Y.; Deighton, J.; Szun, S.; Anagnostou, K.; Ewan, P. A longitudinal study of resolution of allergy to well-cooked and uncooked egg. Clin. Exp. Allergy 2011, 41, 706-712.

33. Shek, L.P.; Soderstrom, L.; Ahlstedt, S.; Beyer, K.; Sampson, H.A. Determination of food specific IgE levels over time can predict the development of tolerance in cow's milk and hen's egg allergy. J. Allergy Clin. Immunol. 2004, 114, 387-391.

34. Komata, T.; Soderstrom, L.; Borres, M.P.; Tachimoto, H.; Ebisawa, M. The predictive relationship of food-specific serum IgE concentrations to challenge outcomes for egg and milk varies by patient age. J. Allergy Clin. Immunol. 2007, 119, 1272-1274.

35. Roberts, G.; Lack, G. Food allergy-Getting more out of your skin prick tests. Clin. Exp. Allergy 2000, 30, 1495-1498.

36. Suh, J.; Lee, H.; Lee, J.H.; Cho, J.; Yu, J.S.; Kim, J.; Han, Y.; Ahn, K.; Lee, S.I. Natural course of cow's milk allergy in children with atopic dermatitis. J. Korean Med. Sci. 2011, 26, 1152-1158.

37. Wood, R.A.; Sicherer, S.H.; Vickery, B.P.; Jones, S.M.; Liu, A.H.; Fleischer, D.M.; Henning, A.K.; Mayer, L.; Burks, A.W.; Grishin, A.; et al. The natural history of milk allergy in an observational cohort. J. Allergy Clin. Immunol. 2013, 131, 805-812.

38. Spergel, J.M. Natural history of cow's milk allergy. J. Allergy Clin. Immunol. 2013, 131, 813-814.

39. Mudd, K.; Paterakis, M.; Curtin-Brosnan, J.; Matsui, E.; Wood, R. Predicting outcome of repeat milk, egg, or peanut oral food challenges. J. Allergy Clin. Immunol. 2009, 124, 1115-1116.

40. Hourihane. J.O.; Roberts, S.A.; Warner, J.O. Resolution of peanut allergy: Case-control study. BMJ 1998, 316, 1271-1275. 
41. Kim, J.; Chung, Y.; Han, Y.; Ahn, K.; Lee, S.-I. The natural history and prognostic factors of egg allergy in Korean infants with atopic dermatitis. Asian Pac. J. Allergy Immunol. 2009, 27, $107-114$.

42. James, J.M.; Sampson, H.A. Immunologic changes associated with the development of tolerance in children with cow milk allergy. J. Pediatr. 1992, 121, 371-377.

43. Crespo, J.F.; Pascual, C.; Ferrer, A.; Burks, A.W.; Diaz Pena, J.M.; Martin Esteban, M. Egg white-specific IgE level as a tolerance marker in the follow up of egg allergy. Allergy Proc. 1994, 15, 73-76.

44. Garcia-Ara, M.C.; Boyano-Martinez, M.T.; Diaz-Pena, J.M.; Martin-Munoz, M.F.; Martin-Esteban, M. Cow's milk-specific immunoglobulin E levels as predictors of clinical reactivity in the follow-up of the cow's milk allergy infants. Clin. Exp. Allergy 2004, 34, 866-870.

45. Hill, D.J.; Firer, M.A.; Ball, G.; Hosking, C.S. Natural history of cows' milk allergy in children: Immunological outcome over 2 years. Clin Exp Allergy 1993, 23, 124-131.

46. Savilahti, E.M.; Saarinen, K,M.; Savilahti, E. Duration of clinical reactivity in cow's milk allergy is associated with levels of specific immunoglobulin G4 and immunoglobulin A antibodies to beta-lactoglobulin. Clin. Exp. Allergy 2010, 40, 251-256.

47. Ford, R.P.; Taylor, B. Natural history of egg hypersensitivity. Arch. Dis. Child. 1982, 57, 649-652.

48. Montesinos, E.; Martorell, A.; Felix, R.; Cerda, J.C. Egg white specific IgE levels in serum as clinical reactivity predictors in the course of egg allergy follow-up. Pediatr. Allergy Immunol. 2010, 21, 634-639.

49. Boyano-Martinez, T.; Garcia-Ara, C.; Diaz-Pena, J.M.; Martin-Esteban, M. Prediction of tolerance on the basis of quantification of egg white-specific IgE antibodies in children with egg allergy. J. Allergy Clin. Immunol. 2002, 110, 304-309.

50. Konstantinou, G.N.; Giavi, S.; Kalobatsou, A.; Vassilopoulou, E.; Douladiris, N.; Saxoni-Papageorgiou, P.; Papadopoulos, N.G. Consumption of heat-treated egg by children allergic or sensitized to egg can affect the natural course of egg allergy: Hypothesis-generating observations. J. Allergy Clin. Immunol. 2008, 122, 414-415.

51. Lemon-Mule, H.; Sampson, H.A.; Sicherer, S.H.; Shreffler, W.G.; Noone, S.; Nowak-Wegrzyn, A. Immunologic changes in children with egg allergy ingesting extensively heated egg. J. Allergy Clin. Immunol. 2008, 122, 977-983.

52. Leonard, S.A.; Sampson, H.A.; Sicherer, S.H.; Noone, S.; Moshier, E.L; Godbold, J.; Nowak-Węgrzyn, A. Dietary baked egg accelerates resolution of egg allergy in children. J. Allergy Clin. Immunol. 2012, 130, 473-480.

53. Yavuz, S.T.; Buyuktiryaki, B.; Sahiner, U.M.; Birben, E.; Tuncer, A.; Yakarisik, S.; Karabulut, E.; Kalayci, O.; Sackesen, C. Factors that predict the clinical reactivity and tolerance in children with cow's milk allergy. Ann. Allergy Asthma Immunol. 2013, 110, 284-289.

54. Santos, A.; Dias, A.; Pinheiro, J.A. Predictive factors for the persistence of cow's milk allergy. Pediatr. Allergy Immunol. 2010, 21, 1127-1134. 
55. DunnGalvin, A.; Daly, D.; Cullinane, C.; Stenke, E.; Keeton, D.; Erlewyn-Lajeunesse, M.; Roberts, G.C.; Lucas, J.; Hourihane, J.O. Highly accurate prediction of food challenge outcome using routinely available clinical data. J. Allergy Clin. Immunol. 2011, 127, 633-639.

56. Varshney, P.; Jones, S.M.; Scurlock, A.M.; Perry, T.T.; Kemper, A.; Steele, P.; Hiegel, A.; Kamilaris, J.; Carlisle, S.; Yue, X.; et al. A randomized controlled study of peanut oral immunotherapy: Clinical desensitization and modulation of the allergic response. J. Allergy Clin. Immunol. 2011, 127, 654-660.

57. Kim, E.H.; Bird, J.A.; Kulis, M.; Laubach, S.; Pons, L.; Shreffler, W.; Steele, P.; Kamilaris, J.; Vickery, B.; Burks, A.W. Sublingual immunotherapy for peanut allergy: Clinical and immunologic evidence of desensitization. J. Allergy Clin. Immunol. 2011, 127, 640-646.

58. Osborne, N.J.; Koplin, J.J.; Martin, P.E.; Gurrin, L.C.; Thiele, L.; Tang, M.L.; Ponsonby, A.L.; Dharmage, S.C.; Allen, K.J.; HealthNuts Study Investigators. The HealthNuts population-based study of paediatric food allergy: Validity, safety and acceptability. Clin. Exp. Allergy 2010, 40, 1516-1522.

59. Kaczmarski, M.; Wasilewska, J.; Cudowska, B.; Semeniuk, J.; Klukowski, M.; Matuszewska, E. The natural history of cow's milk allergy in north-eastern Poland. Adv. Med. Sci. 2013, 58, 22-30.

60. Elizur, A.; Rajuan, N.; Goldberg, M.R.; Leshno, M.; Cohen, A.; Katz, Y. Natural course and risk factors for persistence of IgE-mediated cow's milk allergy. J. Pediatr. 2012, 161, 482-487.e1.

61. Dang, T.D. Characterization of plasma cytokines in an infant population cohort of challengeproven food allergy. Exp. Allergy Immunol. 2013, doi:10.1111/all.12215.

62. Dang, T.D.; Tang, M.; Choo, S.; Licciardi, P.V.; Koplin, J.J.; Martin, P.E.; Tan, T.; Gurrin, L.C.; Ponsonby, A.L.; Tey, D.; et al. Increasing the accuracy of peanut allergy diagnosis by using Ara $\mathrm{h} 2$. J. Allergy Clin. Immunol. 2012, 129, 1056-1063.

63. Ahrens, B.; Lopes de Oliveira, L.C.; Grabenhenrich, L.; Schulz, G.; Niggemann, B.; Wahn, U.; Beyer, K. Individual cow's milk allergens as prognostic markers for tolerance development? Clin. Exp. Allergy 2012, 42, 1630-1637.

64. Marriage, D.E.; Erlewyn-Lajeunesse, M.; Unsworth, D.J.; Henderson, A.J. Unscrambling egg allergy: The daignostic value of specific IgE concentrations and skin prick tests for ovomucoid and egg white in the management of chidlren with hen's egg allergy. Int. Sch. Res. Netw. 2012, doi:10.5402/2012/627545.

65. Jarvinen, K.M.; Beyer, K.; Vila, L.; Bardina, L.; Mishoe, M.; Sampson, H.A. Specificity of IgE antibodies to sequential epitopes of hen's egg ovomucoid as a marker for persistence of egg allergy. Allergy 2007, 62, 758-765.

66. Rubio, A.; Vivinus-Nebot, M.; Bourrier, T.; Saggio, B.; Albertini, M.; Bernard, A. Benefit of the basophil activiation test in deciding when to reintroduce cow's milk in allergic children. Allergy 2011, 66, 92-100.

67. Ford, L.S.; Bloom, K.A.; Nowak-Wegrzyn, A.H.; Shreffler, W.G.; Masilamani, M.; Sampson, H.A. Basophil reactivity, wheal size, and immunoglobulin levels distinguish degrees of cow's milk tolerance. J. Allergy Clin. Immunol. 2013, 131, 180-186.

68. Ocmant, A.; Mulier, S.; Hanssens, L.; Goldman, M.; Casimer, G.; Mascart, F.; Schandené, L. Basophil activiation tests for the diagnosis of food allergy in children. Clin. Exp. Allergy 2009, $39,1234-1245$. 
69. Tan, T.H.; Ellis, J.A.; Saffery, R.; Allen, K.J. The role of genetics and environment in the rise of childhood food allergy. Clin. Exp. Allergy 2012, 42, 20-29.

(C) 2013 by the authors; licensee MDPI, Basel, Switzerland. This article is an open access article distributed under the terms and conditions of the Creative Commons Attribution license (http://creativecommons.org/licenses/by/3.0/). 